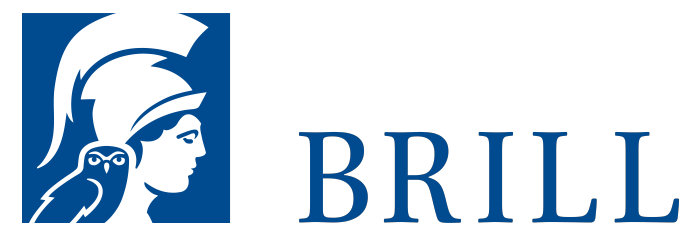

\title{
Entfernte Ähnlichkeiten
}

Zur Geschichte von Witz und ingenium

Author: Ekkehard Knörer

Knörer rekonstruiert am Leifaden von Witz und ingenium die Diskurse von Rhetorik, Poetik und Philosophie, in denen diese Begriffe eine Zentralstellung einnehmen. Er ermöglicht so einen überraschenden Blick auf diskursgeschichtliche Zusammenhänge und macht die Zeit zwischen 1600 und 1800 lesbar als Epoche des Witzes. Am Witz und dem Begriff, den man sich von ihm macht, lassen sich die Umschichtungen der Diskurse, die man auf die Namen von Barock, Klassik, Aufklärung gebracht hat, en détail untersuchen. Was sich später in unterschiedliche Disziplinen klar ausdifferenziert, hängt auf dem umkämpften Schauplatz des Witzes noch zusammen. Es gibt, von heute aus gesehen, eine Rhetorik, eine Poetik und eine philosophische Ästhetik des Witzes. Richtiger wäre es zu sagen, dass sich am Witz das Rhetorische, das Poetische und das Philosophische niemals klar trennen lassen.

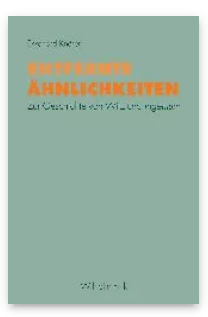

Pages: 248 Seiten, $2 \mathrm{~s} / \mathrm{w}$ Abb. Language: German

Subjects:

General,

Literature and Cultural Studies Publisher: Brill | Fink

E-Book (PDF)

Released online: $13 \mathrm{Jan} 2 \mathrm{O} 2 \mathrm{O}$ ISBN: $978-3^{-}$ 8467-4285-3 List price USD $\$ 30.00$

Paperback Publication date: 21 Nov 2007

ISBN: 978-37705-4285-7 List price USD $\$ 30.00$ 
For more information see brill.com

Order information: Order online at brill.com +44330 333 0049 | customerservices@brill.com Submission information: brill.com/authors

Titles published by Brill | Fink, Brill | mentis or Brill | Schöningh: +49(o)715413279216| brill@brocom.de 